\title{
Optical Properties of CuSCN/Stilbazolium Dye Hybrid Thin Films
}

\author{
L.V. Poperenko ${ }^{1}$, I.V. Yurgelevych ${ }^{1, *}$, D.V. Gnatyuk ${ }^{2}$, K. Uda ${ }^{3}$, T. Yoshida ${ }^{3}$ \\ 1 Taras Shevchenko National University of Kyiv, 64/13, Volodymyrska St., 01601 Kyiv, Ukraine \\ ${ }^{2}$ V. Lashkaryov Institute of Semiconductor Physics, NAS of Ukraine, 41, prospect Nauky, 03680 Kyiv, Ukraine \\ ${ }^{3}$ Graduate School of Science and Engineering, Yamagata University, 4-3-16 Jonan, Yonezawa, \\ Yamagata 9928510, Japan
}

(Received 20 November 2021; revised manuscript received 17 December 2021; published online 20 December 2021)

\begin{abstract}
Ellipsometric diagnostics of hybrid organic-inorganic films of copper thiocyanate CuSCN with stilbazolium dye of different concentrations was carried out. The investigated samples with 4-(N,N-dimethylamino)-4'-( $\mathrm{N}^{\prime}$-methyl) stilbazolium tosylate concentrations of $0,25,250$ and $1000 \mu \mathrm{mol} / \mathrm{dm}^{3}$ were deposited on F-doped tin oxide substrate. To characterize the optical properties of hybrid organic-inorganic films, the angular dependences of such ellipsometric parameters as the phase shift $\Delta$ between $p$ - and $s$-components of the polarization vector and the azimuth $\Psi$ of the restored linear polarization were measured within a wide range of light incidence angles. Due to their angular dependences, the principal angle $\varphi_{p}$ of light incidence and the value of $\operatorname{tg} \Psi_{\min }$ were determined. To characterize the electronic properties of the subsurface layers of the investigated hybrid organic-inorganic films, the refractive $n$ and absorption $k$ indices and the optical conductivity $\sigma$ were defined according to the semi-infinite medium approximation. It was found that an increase in the concentration of stilbazolium dye in hybrid organic-inorganic films from 25 to $250 \mu \mathrm{mol} / \mathrm{dm}^{3}$ leads to an increase in the principal angle of light incidence and the refractive index. However, the behavior of the ellipsometric parameters of a film with a maximum dye concentration of $1000 \mathrm{\mu mol} / \mathrm{dm}^{3} \mathrm{cannot}$ be explained only by an increase in the dye concentration. It was assumed that this modification of the optical properties of hybrid organic-inorganic films with a maximum dye concentration is associated with a structural phase transition from the rhombohedral $\beta$-phase to the orthorhombic $\alpha$-phase of CuSCN at high dye concentrations, which is confirmed by X-ray diffraction data presented in other works. It is concluded that there is no optical anisotropy of the subsurface layers of the studied samples.
\end{abstract}

Keywords: Organic-inorganic films, Optical properties, Ellipsometry, Optical anisotropy.

DOI: 10.21272/jnep.13(6).06033

PACS numbers: 78.68. + m, 81.07.Pr

\section{INTRODUCTION}

The combination of inorganic and organic substances can significantly expand the possibilities for creating new materials. Hybrid inorganic/organic films with new functional properties are promising materials for practical use. Unlike composites, which are formed to simultaneously exploit the best physical properties of each component, hybrid films, due to the chemical interaction between organic and inorganic components, can be formed into structures with completely new properties. In particular, they can simultaneously have high strength, ductility, high corrosion resistance and be sound and heat insulating material. Also, nanostructured hybrid organic-inorganic films, in which one of the components is an organic dye, can be used as a material for solar panels. As a result of the so-called electrochemical self-assembly process, the inorganic component becomes porous with a large surface area, but retains its single crystal structure and, thus, is ideal as a photoanode material in solar cells [1].

In $[2,3]$, the optical and structural properties of hybrid organic-inorganic CuSCN films with stilbazolium dye (4-(N,N-dimethylamino)-4'-( $\mathrm{N}^{\prime}$-methyl) stilbazolium tosylate (DAST) were studied by optical spectroscopy, photoluminescence, X-ray diffraction and scanning electron microscopy. Using X-ray diffraction, it was found that at high concentrations of DAST dye there is the structural phase transition from the rhombohedral $\beta$-phase to the orthorhombic $\alpha$-phase of CuSCN. Using the method of scanning electron microscopy, it was shown that a change in the dye concentration leads to a sharp change in the morphology of the film. At a dye concentration of $250 \mu \mathrm{mol} / \mathrm{dm}^{3}$, a unique nanostructure similar to a "comb" appears. In this case, DAST in the form of a separate phase fills in the gaps between the "teeth of the comb". An analysis of the obtained absorption spectra allowed the authors of [2] to detect a blue shift of the absorption maximum (from $499 \mathrm{~nm}$ at $\mathrm{DAST}=50 \mu \mathrm{mol} / \mathrm{dm}^{3}$ to $487 \mathrm{~nm}$ at $\mathrm{DAST}=$ $500 \mu \mathrm{mol} / \mathrm{dm}^{3}$ ). A narrowing of this maximum was also observed with increasing dye concentration. These changes in the optical properties were associated with a greater ordering of the dye structure.

To obtain hybrid films with controlled properties it is necessary, first of all, to investigate these properties by various experimental techniques. Ellipsometry has proven to be an effective method for studying the optical properties and parameters of thin films as it is a highly sensitive non-contact and therefore nondestructive technique [4].

The aim of the work was to study by ellipsometric method the optical properties of hybrid organicinorganic films of copper thiocyanate CuSCN with stilbazolium dye of different concentrations obtained in the process of electrochemical self-assembly.

\footnotetext{
*vladira_19@ukr.net
} 


\section{SAMPLES AND RESEARCH METHODS}

Hybrid organic-inorganic films of copper thiocyanate $\mathrm{CuSCN}$ with stilbazolium dye of different concentrations were deposited on F-doped tin oxide substrate. Accordingly, these samples had varying degrees of red color. One sample was a transparent CuSCN film on the substrate (\#1). The concentration of stilbazolium dye, namely 4-(N,N-dimethylamino)-4'-(N'-methyl) stilbazolium tosylate (DAST), of other three samples was $25(\# 2), 250(\# 3)$ and $1000(\# 4) \mu \mathrm{mol} / \mathrm{dm}^{3}$. This organic component was combined with inorganic CuSCN during electrodeposition fabrication. This process is called electrochemical self-assembly [2]. As a result, a hybrid organic-inorganic film was formed on the substrate surface: an electrochemically self-assembled CuSCN/ stilbazolium dye hybrid thin film. The thickness of the film samples was about $800 \mathrm{~nm}$. The process of production of these samples is described in detail in $[2,3]$.

Optical polarization measurements were carried out using an LEF-3M-1 laser ellipsometer at a wavelength of $632.8 \mathrm{~nm}$ under atmospheric conditions. For hybrid organic-inorganic films of copper thiocyanate CuSCN with stilbazolium dye, such ellipsometric parameters as the phase shift $\Delta$ between $p$ - and $s$-components of the polarization vector and the azimuth $\Psi$ of the restored linear polarization [4] were measured in the wide range of angles $\varphi$ of the light incidence. All angular dependences of the ellipsometric parameters $\cos \Delta(\varphi)$ and $\operatorname{tg} \Psi(\varphi)$ of the investigated samples were analyzed and the principal angle $\varphi_{p}(\cos \Delta=0)$ of light incidence and the minimum value $\operatorname{tg} \Psi_{\text {min }}$ were obtained. The errors in determining the ellipsometric parameters were $\delta \varphi_{p}= \pm 0.1^{\circ}$ and $\delta \operatorname{tg} \Psi_{\min }= \pm 0.01$, respectively.

To estimate the electronic properties of the surface layers of the investigated hybrid organic-inorganic films of copper thiocyanate CuSCN with stilbazolium dye of different concentrations, the optical conductivity $\sigma$ was calculated according to the semi-infinite medium approximation:

$$
\begin{aligned}
n & =\sin \varphi_{p} \operatorname{tg} \varphi_{p} \cos 2 \Psi_{p}, \\
k & =\sin \varphi_{p} \operatorname{tg} \varphi_{p} \sin 2 \Psi_{p}, \\
\sigma & =n k c / \lambda,
\end{aligned}
$$

where $n$ is the refractive index, $k$ is the absorption in$\operatorname{dex}, c$ is the light speed, $\sigma$ is the optical conductivity, $\varphi_{p}$ is the principal angle, $\Psi_{p}$ is the azimuth $\Psi$ at $\varphi_{p}$.

In $[5,6]$, ellipsometry has proven to be an effective method for diagnosing optical anisotropy in the subsurface layers of materials. Therefore, in this work, the dependences of the ellipsometric parameters $\cos \Delta$ and $\operatorname{tg} \Psi$ on the azimuthal angle $\alpha$ of rotation of the studied samples in their own planes at a certain angle of light incidence were also measured. The samples were rotated in their own planes with an interval of $5-10^{\circ}$.

\section{RESULTS AND DISCUSSION}

The angular dependences of the ellipsometric parameters $\cos \Delta$ and $\operatorname{tg} \Psi$ obtained for all investigated samples of hybrid organic-inorganic films of copper thiocyanate CuSCN with stilbazolium dye are shown in Fig. 1. It is seen that the behavior of the $\cos \Delta(\varphi)$ and $\operatorname{tg} \Psi(\varphi)$ curves for sample \#1 (copper thiocyanate
CuSCN film without stilbazolium dye) strongly differs from the behavior of ellipsometric parameters for the other three samples (\#2, \#3, and \#4) of hybrid organicinorganic films of copper thiocyanate CuSCN with stilbazolium dye. In particular, a minimum is observed on the $\cos \Delta(\varphi)$ curve for sample \#1 at an angle of light incidence of $61^{\circ}$.

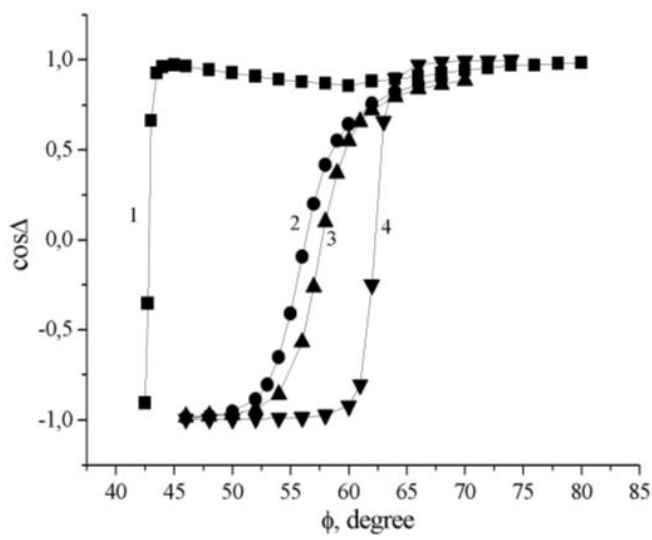

a

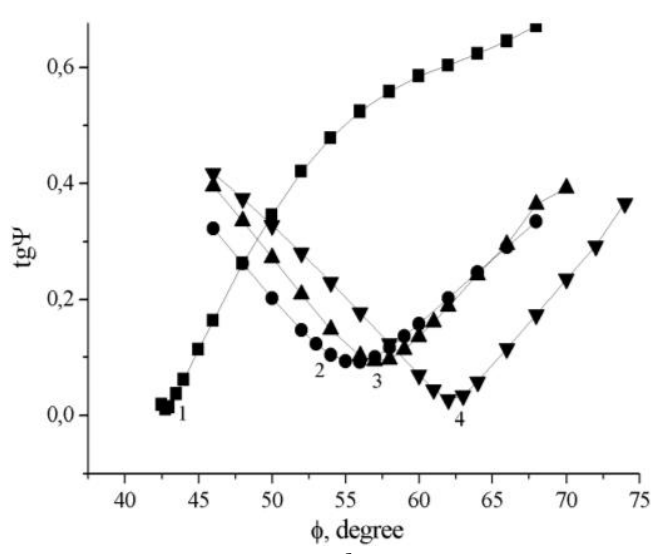

$\mathrm{b}$

Fig. 1 - Dependences of $\cos \Delta(\varphi)$ (a) and $\operatorname{tg} \Psi(\varphi)$ (b) of hybrid organic-inorganic films of copper thiocyanate CuSCN with stilbazolium dye of different concentrations; $q$ : $q=0$ (curve 1), $q=25 \mu \mathrm{mol} / \mathrm{dm}^{3} \quad$ (curve 2), $q=250 \mu \mathrm{mol} / \mathrm{dm}^{3} \quad$ (curve 3), and $q=1000 \mu \mathrm{mol} / \mathrm{dm}^{3}$ (curve 4)

Table 1 - The values of ellipsometric and optical parameters of hybrid organic-inorganic films of CuSCN copper thiocyanate with stilbazolium dye of different concentrations

\begin{tabular}{|c|c|c|c|c|c|}
\hline $\begin{array}{c}q, \\
\mu \mathrm{mol} / \mathrm{dm}^{3}\end{array}$ & $\varphi_{p},{ }^{\circ}$ & $\operatorname{tg} \Psi_{\min }$ & $n$ & $k$ & $\sigma, 10^{14} \mathrm{~s}^{-1}$ \\
\hline 25 & 56.26 & 0.092 & 1.22 & 0.24 & 1.39 \\
\hline 250 & 57.71 & 0.094 & 1.31 & 0.25 & 1.55 \\
\hline 1000 & 62.23 & 0.026 & 1.68 & 0.10 & 0.80 \\
\hline
\end{tabular}

Probably, the $\cos \Delta(\varphi)$ and $\operatorname{tg} \Psi(\varphi)$ curves have such a form due to the large thickness of the transparent CuSCN film and the presence of interference effects. Thus, the values of $\varphi_{p}, \operatorname{tg} \Psi_{\min }, n, k$ and $\sigma$ were obtained for samples \#2, \#3, and \#4 only (Table 1).

One can see that for the hybrid CuSCN-DAST film with the lowest dye concentration of $25 \mu \mathrm{mol} / \mathrm{dm}^{3}$, there is a smooth dependence of the ellipsometric parameters on the angle of light incidence (Fig. 1).

Similar angular dependences of the ellipsometric 
parameters were obtained for sample \#3 with a dye concentration of $250 \mu \mathrm{mol} / \mathrm{dm}^{3}$. But for sample \#3, a certain increase in the principal angle of light incidence and the value of the angular position of the minimum azimuth of linear polarization by about $1.5^{\circ}$ is observed compared to sample \#2. Such an increase in $\varphi_{p}$ for a weakly absorbing medium, namely, the studied films at a wavelength of $632.8 \mathrm{~nm}$, can be explained primarily by an increase in the refractive index due to an increase in the dye concentration.

From Fig. 1, it is seen that the behavior of the ellipsometric parameters for sample \#4 with a maximum dye concentration of $1000 \mu \mathrm{mol} / \mathrm{dm}^{3}$ differs significantly from the one for samples \#2 and \#3. First, the phase shift is characterized by a sharper change from -1 to +1 near the principal angle, and second, the value of the azimuth of the restored linear polarization in the minimum decreases more than 3 times compared to the similar values for samples \#2 and \#3.

That is, sample \#4 in its optical properties is closer to an ideal dielectric than samples \#2 and \#3. The value of optical conductivity for sample \#4 is also significantly lower compared to samples \#2 and \#3. This behavior of the ellipsometric and optical parameters of the hybrid CuSCN-DAST film cannot be explained only by an increase in the dye concentration.

Using X-ray diffraction, it was found [2,3] that at high concentrations of DAST (approximately 700-800 $\mu \mathrm{mol} / \mathrm{dm}^{3}$ ) there is a structural phase transition from the rhombohedral $\beta$-phase to the orthorhombic $\alpha$-phase of CuSCN in hybrid CuSCN-DAST films. It is likely that significant changes in the optical properties of the investigated sample \#4 with a high dye concentration of $1000 \mathrm{\mu mol} / \mathrm{dm}^{3}$ are also associated with similar changes in the structure of the hybrid CuSCN-DAST film, and not only with changes in the dye concentration.

In this work, ellipsometric diagnosis of the optical anisotropy of the studied hybrid organic-inorganic CuSCN-DAST films was also performed. In Fig. 2b, the dependences of the ellipsometric parameters $\cos \Delta$ and $\operatorname{tg} \Psi$ on the azimuthal angle $\alpha$ of rotation of sample \#3 in its own plane are presented at an angle of light incidence of $58^{\circ}$. It is seen that the ellipsometric parameters do not change significantly when the azimuthal angle $\alpha$ changes. Similar dependences of the ellipsometric parameters were obtained for other samples of the investigated films. Therefore, optical anisotropy for the studied samples of hybrid organic-inorganic CuSCN-DAST films was not observed.

\section{CONCLUSIONS}

It was found that the behavior of the ellipsometric

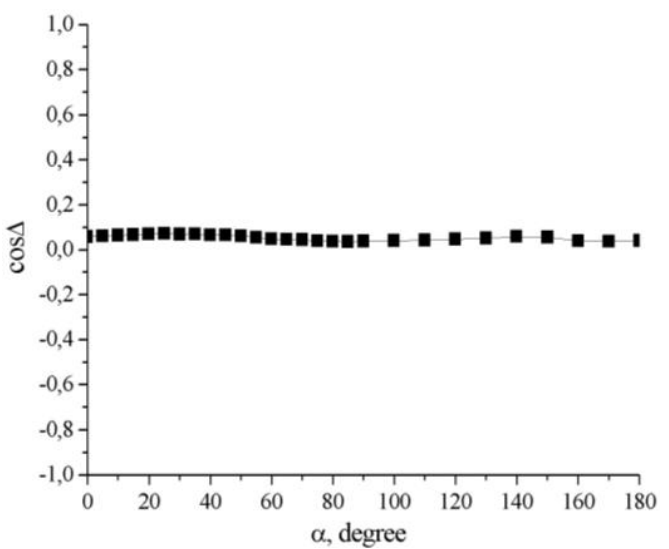

a

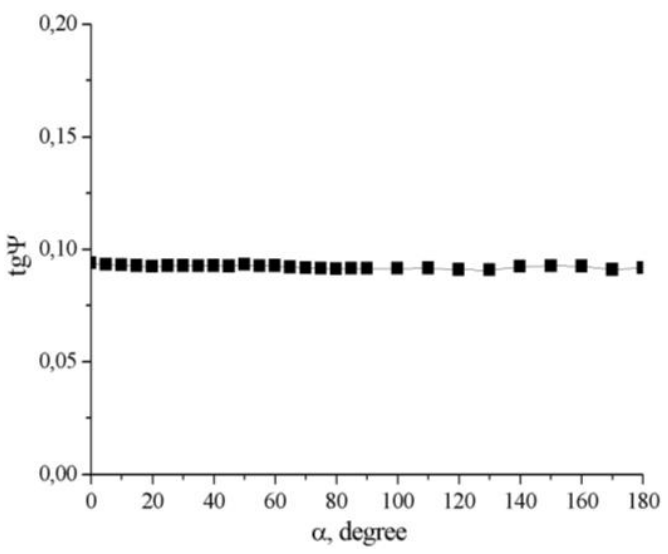

b

Fig. 2 - Dependences of $\cos \Delta$ (a) and $\operatorname{tg} \Psi$ (b) on the azimuthal angle of rotation $\alpha$ of sample \#3 in its own plane at an angle of light incidence of $58^{\circ}$

and optical parameters of hybrid organic-inorganic CuSCN-DAST films with low dye concentrations (sample \#2 $\left(25 \mu \mathrm{mol} / \mathrm{dm}^{3}\right)$ and sample \#3 $\left.\left(250 \mu \mathrm{mol} / \mathrm{dm}^{3}\right)\right)$ can be associated with changes in the dye concentration. Namely, its growth for sample \#3 leads to an increase in the principal angle of light incidence and the refractive index.

It was established that changes in the optical properties of the hybrid organic-inorganic CuSCN-DAST film with a high dye concentration of $1000 \mu \mathrm{mol} / \mathrm{dm}^{3}$ are associated not only with an increase in the dye concentration, but also with the structural phase transition from the rhombohedral $\beta$-phase to the orthorhombic $\alpha$-phase of CuSCN.

It was found that the investigated samples of hybrid organic-inorganic CuSCN-DAST films are optically isotropic.

\section{REFERENCES}

1. K. Uda, Yu. Tsuda, Sh. Okada, R. Yamakado, L. Sun, Yo. Suzuri, M.Sch. White, M. Furis, Ph. Stadler, O. Dimitriev, T. Yoshida, ECS Transactions 88, 323 (2018).

2. Yu. Tsuda, H. Sun, L. Sun, Sh. Okada, A. Masuhara, Ph. Stadler, N.S. Sariciftci, M.Sch. White, T. Yoshida, Monatsh. Chem. 148, 845 (2017).

3. K. Uda, Yu. Tsuda, Sh. Okada, R. Yamakado, L. Sun, Yo. Suzuri, M.Sch. White, M. Furis, Ph. Stadler, O. Dimitriev, T. Yoshida, ACS Omega 4, 4056 (2019).

4. D. Gonçalves, E.A Irene, Quim. Nova 25, 794 (2002).

5. T. Aoki, D. Gnatyuk, L. Melnichenko, L. Poperenko, I. Yurgelevych, Lect. Notes Netw. Syst. 53, 66 (2019).

6. L. Poperenko, V. Stukalenko, I. Yurgelevych, J. NanoElectron. Phys. 11, No 303032 (2019). 


\title{
Оптичні властивості гібридних тонких плівок CuSCN/стільбазоліевий барвник
}

\author{
Л.В. Поперенко ${ }^{1}$ I.В. Юргелевич ${ }^{1}$, Д.В. Гнатюк ${ }^{2}, \mathrm{~K} . \mathrm{Uda}^{3}$, T. Yoshida ${ }^{3}$ \\ ${ }^{1}$ Київський національний університет ілені Тараса Шевченка, вул. Володилирська, 64/13, \\ 01601 Київ, Украӥна \\ 2 Інститут фбізики напівпровідників ілені В.С. Лашкарьова, НАН Украӥни, проспект Науки, 41, \\ 03680 Київ, Україна \\ ${ }^{3}$ Graduate School of Science and Engineering, Yamagata University, 4-3-16 Jonan, Yonezawa, \\ Yamagata 9928510, Japan
}

Проведено еліпсометричну діагностику гібридних органічно-неорганічних плівок тіоціанату міді CuSCN зі стільбазолієвим барвником різної концентрації. Досліджені зразки з концентраціями барвника 4-N,N-диметиламіно-4'- $\mathrm{N}^{\prime}$-метил-стільбазоліум тозілат, що дорівнювали $0,25,250$ та 1000 мкмоль/дм ${ }^{3}$, було нанесено на підкладки з оксиду олова, допованого фртором. Для характеризації оптичних властивостей гібридних органічно-неорганічних плівок вимірювались кутові залежності таких еліпсометричних параметрів як зсув фаз $\Delta$ між $p$ - та $s$-компонентами вектора поляризації та азимут $\Psi$ відновленої лінійної поляризації в широкому інтервалі кутів падіння світла. 3 їх кутових залежностей визначались головний кут падіння світла $\varphi_{p}$ та величина $\operatorname{tg} \Psi_{\min }$. Для характеризації електронних властивостей досліджених гібридних органічно-неорганічних плівок було визначено показники заломлення $n$ і поглинання $k$ та оптичну провідність $\sigma$ у моделі напівнескінченного середовища. Знайдено, що зростання концентрації стільбазоліевого барвника в гібридних органічно-неорганічних плівках з 25 до 250 мкмоль/дм ${ }^{3}$ призводить до збільшення головного кута падіння світла та показника заломлення. Але поведінку еліпсометричних параметрів для плівки з максимальною концентрацією барвника 1000 мкмоль/дм ${ }^{3}$ не можна пояснити лише збільшенням концентрації барвника. Ймовірно, така модифікація оптичних властивостей гібридних органічно-неорганічних плівок з максимальною концентрацією барвника пов'язана зі структурним фазовим переходом від ромбоедричної $\beta$-фази до орторомбічної $\alpha$-фази CuSCN при високих концентраціях барвника, що підтверджуеться даними дифракції рентгенівських променів у інших роботах. Зроблено висновок про відсутність оптичної анізотропії приповерхневих шарів плівок.

Ключові слова: Органічно-неорганічні плівки, Оптичні властивості, Еліпсометрія, Оптична анізотропія. 